\title{
Ecological stoichiometry of microbial biomass carbon, nitrogen and phosphorus on bauxite residue disposal areas
}

by Cheng, Q., Xue, R., Wu, H., Hartley, W., Zhang, Y., Zhou, L. and Xue, S.

Copyright, publisher and additional information: .This is the authors' accepted manuscript. The published version is available via Taylor \& Francis.

Please refer to any applicable terms of use of the publisher.

DOI: https://doi.org/10.3382/ps/pez495 
Ecological stoichiometry of microbial biomass carbon, nitrogen and phosphorus in bauxite residue

Qingyu Cheng ${ }^{\mathrm{a}}$, Rui Xue, Hao Wu ${ }^{\mathrm{a}}$, William Hartley ${ }^{\mathrm{b}}$, Yifan Zhang ${ }^{\mathrm{a}}$, Lean Zhou, Shengguo Xue ${ }^{\mathrm{a}, *}$,

${ }^{a}$ School of Metallurgy and Environment, Central South University, 932 Lushan South Road, Changsha, Hunan, 410083, PR China

${ }^{\mathrm{b}}$ Crop and Environment Sciences Department, Harper Adams University, Newport, Shropshire, TF10 8NB,United Kingdom

${ }^{*}$ Correspondence author: Shengguo Xue; E-mail address: sgxue@,csu.edu.cn 


\begin{abstract}
During the process of ecological succession on bauxite residue disposal areas (BRDAs), nutrients accumulate as a result of microbial activity. Over time the residue is converted into a soil-like material, and as this ecosystem gradually stabilizes, plant establishment begins. The role of microorganisms in nutrient cycling however remains elusive on bauxite residue. Carbon $(\mathrm{C})$, nitrogen $(\mathrm{N})$ and phosphorus $(\mathrm{P})$ ecological stoichiometry is a critical indicator of nutrient cycling in an ecosystem. In this study, we measured C, $\mathrm{N}$, and $\mathrm{P}$ contents and microbial biomass carbon (MBC), nitrogen (MBN), and phosphorus (MBP) contents in bauxite residue in chronological stacks of residue, analyzing their ecological stoichiometric characteristics to investigate changes in nutrients following long-term natural weathering process. Results revealed that organic carbon (OC), total nitrogen (TN) and available phosphorus (AP) significantly increased with time, but total phosphorus (TP) decreased. Bauxite residue C/P and N/P increased significantly with an increase in stacking age. MBC/MBN decreased significantly whilst MBC/MBP and MBN/MBP increased significantly with stacking age. Carbon, N, P and MBC, MBN, MBP in bauxite residue correlated significantly, indicating that microbial biomass can be used as a biological indicator to evaluate bauxite residue quality. This study revealed that BRDA ecosystem development reaches homeostasis gradually, whilst CNP substrate ratio and microbes can be used as an effective tool to gain insight into nutrient cycling.
\end{abstract}

Key words: Bauxite residue . CNP . Microbial biomass . Ecological stoichiometry 


\section{Introduction}

Bauxite residue is a highly alkaline solid hazardous waste produced from bauxite processing for alumina production. It has a high salt content, poor nutrient status and is a potential threat to the surrounding environment (Zhu et al. 2018). Plant growth is hindered on bauxite residue because of its poor physical condition and chemical properties, as well as the associated nutrient deficiencies. Spontaneous colonization of bauxite residue disposal areas (BRDAs) by vegetation can stabilize the surface against wind and water erosion, increase organic matter and promote aggregation of the residue (Zhu et al. 2016a; Kong et al. 2017a). A number of studies have revealed that natural weathering processes can ameliorate the residues, to the extent that a suitable environment is created for plant establishment (Zhu et al. 2016b; Santini and Peng 2017). Freshly stacked residues, having a high bulk density, low porosity and poor aggregate stability, were transformed into soil-like material through long-term natural processes, and this transformation supports the growth of herbaceous plants (Santini and Martin 2013). Plant growth reduced $\mathrm{pH}$ and exchangeable sodium percentage (ESP), increased organic matter, possibly due to the interaction of their roots and associated rhizosphere microorganisms (Zhu et al. 2016a). Recent research has demonstrated that it's possible for surface revegetation by Bermuda grass (Cynodon dactylon) combined with arbuscular mycorrhizal fungi and giant reeds (Arundo donax L.) ( Babu and Reddy 2011; Alshaal et al. 2013; Kong et al. 2017).

During the ecological restoration process, microorganisms are sensitive to environmental change and therefore can be an indicator to some degree (He et al. 2003). Microorganisms participate in biochemical processes such as decomposition, formation of humus and conversion of nutrients in ecosystems. They are the driving force for the transformation of plant nutrients and have key effects in the process of material circulation and energy flow (Zhao et al. 2016). Carbon (C), nitrogen (N) and phosphorus $(\mathrm{P})$ are the basis of the chemical compositions of all life on the earth. They are the core of geochemical nutrient cycle and are extremely important ecological 
factors in an ecosystem. On the ecosystem scale, the composition of $\mathrm{C}, \mathrm{N}$ and $\mathrm{P}$ in the environment determines the main processes, such as energy flow and material circulation (Elser et al. 2000; Peri et al. 2008; Christine et al. 2015). Microbial biomass is a reservoir of active soil nutrients, and although it accounts for only a small part of the soil organic matter, microbial biomass has a great effect and the nutrients are highly available. Therefore, it is part of the dynamic organic matter in soil, as well as the "source" and "library" of nutrient elements such as nitrogen and phosphorus which include bacteria, fungi, actinomycetes and protozoa, but excludes plants (Mazzarino et al. 1993; Jia et al. 2016). Microbial biomass is an important parameter for characterizing material circulation and energy flow in ecosystems. The greater the value, the more active the microorganisms are, and to some extent, the stronger the material circulation capacity of the ecosystem (Zhao et al. 2013).

Ecological stoichiometry mainly studies the energy balance of ecosystems and the proportional relationships between chemical elements. At present, most research focuses on the link between carbon, nitrogen and phosphorus, and their ecological stoichiometry can reflect nutrient cycling in this system (Anderson et al. 2004). The earliest studies of ecological stoichiometry have mainly been carried out in aquatic ecosystems, but there are biological and environmental differences between aquatic systems and terrestrial systems. These differences have hindered analyses of community and ecosystem structure of diverse habitats. Ecological stoichiometry provides an integrated approach to this type of analysis, because all organisms are composed of the same major elements (C, N, P). In summary, ecological stoichiometry provides a novel idea for studying the biogeochemical cycles and ecochemical processes of C, N, P and other major elements, and is an important ecological indicator in the biogeochemical cycle (Elser et al. 2000). So far, research on ecological stoichiometry of MBC, MBN and MBP has focused on successional changes in soil stoichiometry on abandoned lands, the influence of soil saline-alkali stress on nutrient homeostasis and nutrient stoichiometric ratio changes during ecological restoration of copper mine tailings (Jiao et al. 2013; Li et al. 2018; Wang et al. 2018). These analyses are helpful to understand the biological processes and nutrient cycling in terrestrial 
ecosystems (Yuan et al. 2011).

In this study, bauxite residue from different stacking years on a BRDA in Zhongzhou, Henan Province, was selected to study changes in nutrient concentrations and ecological stoichiometry as a result of natural weathering processes. Our objectives were to: (1) examine $\mathrm{C}, \mathrm{N}, \mathrm{P}$ and their stoichiometric characteristics from different aged residues; (2) examine how ecological stoichiometric characteristics of MBC, MBN, and MBP vary according to stacking age and depth; (3) characterize the relationships between these parameters examined in (1) and (2). Based on these three objectives, we also analyze the homeostasis of the ecosystem on BRDAs, in an attempt to provide a theoretical basis for vegetation restoration.

\section{Materials and methods}

\section{Sample preparation}

Residue samples were collected from an aluminum enterprise in Central China. The climate is warm temperate continental monsoon, with an average annual precipitation of $600-1200 \mathrm{~mm}$ and an annual average temperature of $12.8-14.8^{\circ} \mathrm{C}$. There is abundant rainfall, although its distribution between seasons varies, but mainly concentrated during the summer months.

According to field investigations, five zones related to disposal age were selected, including 1-year-old residue (BR1), 5-year-old residue (BR5), 10-year-old residue (BR10), 15-year-old residue (BR15), and 20-year-old residue (BR20). Natural colonization of herbaceous plants appeared on the 20 -year-old residue, and soil near the BRDAs was collected as a control (CK). At each zone, three sub-samples with a distance of $5 \mathrm{~m}$ were collected to form a representative sample. The residues were sampled to three depths, $20 \mathrm{~m}, 40 \mathrm{~m}$, and $60 \mathrm{~m}$, at each location. Samples were then stored in polyethylene bags, returned to the laboratory, air dried for 1 week, and subsequently sieved $(<2 \mathrm{~mm})$ prior to analysis. 


\section{Chemical analysis}

$\mathrm{pH}$ and electrical conductivity (EC) were determined using residue:water $=1: 5$. Organic carbon (OC) was determined by low-temperature external-heat potassium dichromate oxidation colorimetric method. OC was oxidized by potassium dichromate (100 ${ }^{\circ} \mathrm{C}, 90 \mathrm{~min}$ ), and part of $\mathrm{Cr}^{6+}$ was reduced to $\mathrm{Cr}^{3+}$, then the absorbance of $\mathrm{Cr}^{3+}$ was determined by colorimetry. For total nitrogen $(\mathrm{TN})$, samples were diluted with sulfuric acid, then determined by the semi-micro-Kjeldahl method. Available phosphorus (AP) was extracted using $0.5 \mathrm{~mol} \cdot \mathrm{1}^{-1} \mathrm{NaHCO}_{3}$, and then determined by molybdenum antimony anti-colorimetry.

\section{Biological analysis}

$\mathrm{MBC}, \mathrm{MBN}$ and MBP were determined by chloroform fumigation extraction (Brookes et al. 1982; Brookes et al. 1985). MBC and MBN were extracted with potassium sulfate. Two pre-cultured residue samples $(25 \mathrm{~g})$ were dried and then extracted with $0.5 \mathrm{~mol} / \mathrm{L}$ $\mathrm{K}_{2} \mathrm{SO}_{4}$ solution. The samples were shaken at $300 \mathrm{r} / \mathrm{min}$ for $30 \mathrm{~min}$. The remaining two portions were fumigated with chloroform in a vacuum desiccator for $24 \mathrm{~h}$, and then chloroform was removed for extraction immediately. An equal amount of the extract was mixed with $2 \%$ sodium hexametaphosphate and measured by a total organic carbon (TOC) analyzer. TN in the extract was determined by a Kjeldahl digestion-automatic nitrogen analyzer.

Bauxite residue $\mathrm{MBC}$ was calculated by multiplying the difference between OC extracted by fumigated and non-fumigated residues with the conversion coefficient $\mathrm{K}_{\mathrm{C}}$ (2.22). $\mathrm{MBN}$ is the same as $\mathrm{MBC}\left(\mathrm{K}_{\mathrm{N}}(2.22)\right)$. MBP was determined by sodium carbonate extraction-molybdenum antimony anti-colorimetry. After drying, $4 \mathrm{~g}$ of each pre-cultured residue was either directly extracted with $0.5 \mathrm{~mol} / \mathrm{L} \mathrm{NaHCO}_{3}(\mathrm{pH} 8.5)$, or fumigated with chloroform in a vacuum desiccator for $24 \mathrm{~h}$, and then extracted with chloroform. The phosphorus in the extracted solution was then determined by colorimetry, and the extraction recovery of phosphorus was determined by adding 
inorganic phosphorus. MBP was calculated by multiplying the difference between extracted P from fumigated and non-fumigated residues, which was then corrected using the conversion coefficient $\mathrm{K}_{\mathrm{P}}(2.5)$.

\section{Statistical analysis}

Data were statistically treated with Microsoft Excel 2003, IBM SPSS r. 19.0 and OriginLab ${ }^{\circledR}$ Origin ${ }^{\circledR}$ r. 8.0. Stacking samples with different chronosequences were individually determined using one-way ANOVA (analysis of variance) and homogeneity of variance tests. Pearson correlation coefficient was carried out to determine the relationships between $\mathrm{C}, \mathrm{N}, \mathrm{P}$ and $\mathrm{MBC}, \mathrm{MBN}, \mathrm{MBP}$ in different chronosequences.

\section{Results and discussion}

\section{Characteristics of chemical and microbial biomass indices in bauxite residue}

During natural weathering, the composition and concentrations of $\mathrm{C}, \mathrm{N}$ and $\mathrm{P}$ in bauxite residue from the different storage ages, can reflect changes in nutrients. Natural weathering significantly increased the chemical properties of bauxite residue $(P<0.05)$. At the depth of $0-20 \mathrm{~cm}, \mathrm{OC}$, TN and AP, were $5.7 \sim 10.8 \mathrm{~g} / \mathrm{kg}, 0.05 \sim 0.87 \mathrm{~g} / \mathrm{kg}$ and $0.005 \sim 0.024 \mathrm{~g} / \mathrm{kg}$, respectively (Fig. 1). These increases over time revealed that natural weathering was beneficial to the accumulation of nutrients. During disposal, alkaline mineral phases gradually change with the reduction in $\mathrm{pH}$, and the acid-base environment suitable for microbial survival is gradually reached (Santini and Martin 2013). Previous studies have found that natural weathering of bauxite residue is conducive to the formation of residue aggregates, which improves porosity and water content, and therefore its overall physical condition, which therefore increases microbial diversity (Zhu et al. 2016a). The increase in species richness and quantity of microorganisms can promote carbon sequestration and nitrogen fixation. Some 
microorganisms can convert $\mathrm{CO}_{2}$ in the atmosphere into carbohydrates, whilst biological nitrogen fixation may enhance nitrogen content and its long-term accumulation (Zhang et al. 2012). Plant growth has been observed on BRDAs that have been stored for 20 years. Vegetation coverage, decomposition of plant litter and animal debris, is more conducive to carbon and nitrogen accumulation, which also provides a comfortable living environment for microbial activity.
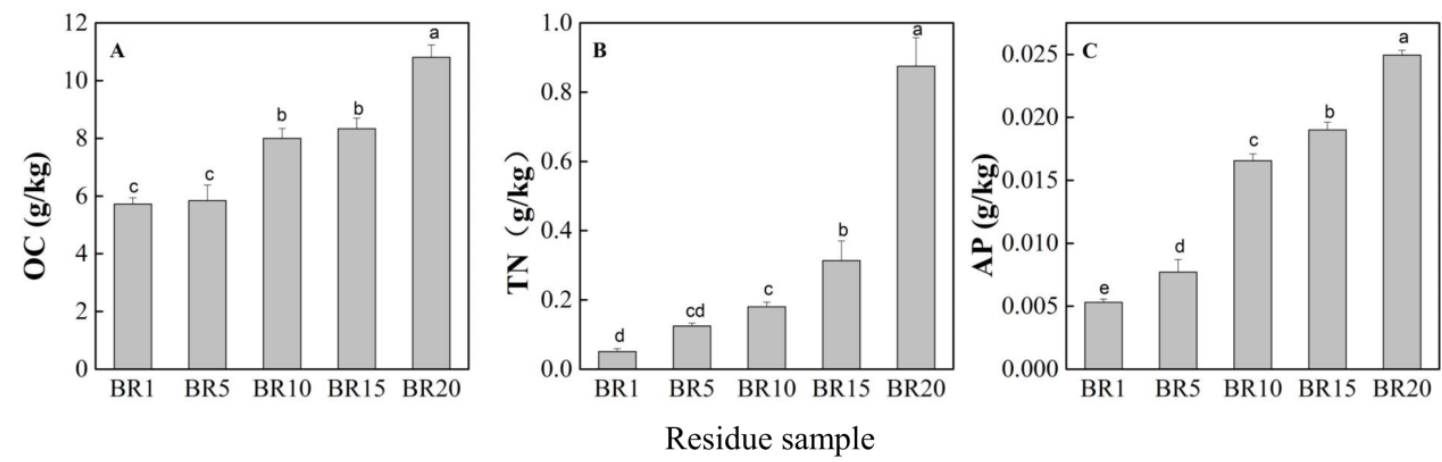

Fig. 1 OC, TN and AP contents of bauxite residues in different stacking ages. Different lowercase letters indicate significant differences $(P<0.05)$.

Microbial biomass reflects the retention of $\mathrm{C}, \mathrm{N}$ and $\mathrm{P}$; a reduction in biomass leads to mineralization of nutrients, and an increase leads to nutrient retention (McGill et al. 1986). When describing the influence of natural weathering processes on nutrient ecological stoichiometry, effective nutrients $(\mathrm{C}, \mathrm{N}$ and $\mathrm{P})$ are better predictors than total nutrients. MBC, MBN and MBP reflect the absorption and transformation of nutrients by microorganisms. During disposal, changes in MBC, MBN and MBP were similar to OC, TN and AP; all of them increased significantly with stacking time $(P<0.05)$, illustrating the impact of natural weathering on microbial biomass ecological stoichiometry. MBC and MBN increased significantly with stacking age $(P<0.05)$, MBC stabilized at $167.57 \mathrm{mg} / \mathrm{kg}$ and MBN reached $37.37 \mathrm{mg} / \mathrm{kg}$ in BR20. While MBP increased significantly during storage from 1 to 10 years $(P<0.05)$, it then remained stable for 10 to 15 years, followed by a significant increase $(P<0.05)$. This indicates an improvement in microbial activity, thus in the presence of microorganisms, the nutrients 
were efficiently transformed and accumulated. As there is minimal human disturbance at the BRDAs, with no material migration or removal, $\mathrm{OC}$ and $\mathrm{TN}$ contents in BR20 were the greatest, as well as $\mathrm{C}$ and $\mathrm{N}$ sequestered by microbes. In the bauxite residue stockpiled for 20 years, MBP reached the greatest value, $5.92 \mathrm{mg} / \mathrm{kg}$. This may be because BR20 contains the most abundant OC and the greatest microbial activity, so microbes were able to dissolve inorganic phosphorus and improve its retention.
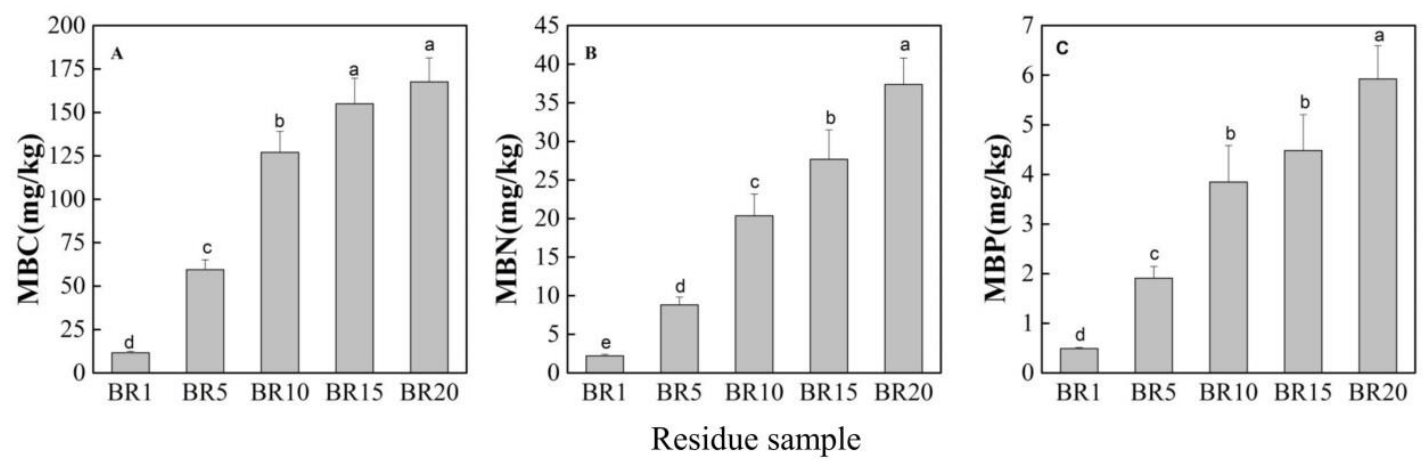

Fig. 2 MBC, MBN and MBP contents of bauxite residues in different stacking ages. Different lowercase letters indicate significant differences $(P<0.05)$.

Depth also affects nutrient accumulation, with nutrient cycling being more efficient at the surface. In residue stocked for 20 years, OC, TN, TP and MBC, MBN, MBP changed significantly from the surface to the base of the stack (Table 1, $P<0.05$ ). As depth increases, OC and TN revealed similar distribution trends. They decreased from 10.81 to $3.88 \mathrm{~g} / \mathrm{kg}$ and 0.87 to $0.16 \mathrm{~g} / \mathrm{kg}$, whilst TP increased from 0.45 to 0.61 $\mathrm{g} / \mathrm{kg}$. Among the different depths, MBC, MBN and MBP demonstrated similar depthrelated patterns, with the greatest values of $167.6,37.4$ and $5.9 \mathrm{mg} / \mathrm{kg}$ on the surface of BR20, respectively. This may be due to improved aeration at the surface. Additionally, carbon and nitrogen fixation by microorganisms will promote the accumulation of OC and TN. Furthermore, microorganisms can secrete organic acids to dissolve phosphorus, which may then be washed down to the lower layers with rainwater runoff, so the TP content in the residue is low. 


\section{Ecological stoichiometric characteristics of chemical and microbial biomass indices in bauxite residue}

Ratios of $\mathrm{C}, \mathrm{N}$ and $\mathrm{P}$ are susceptible to soil formation factors such as the rate of parent material weathering, and this is the same for bauxite residue. Therefore, the ratio can be used to evaluate the nutrient status and quality of bauxite residue (Santini and Banning 2016). In this study, the C:N ratio in bauxite residue from the different stacking years varied from 12.41 to 101.45 , the C:P from 8.81 to 24.28 , and $\mathrm{N}: \mathrm{P}$ from 0.08 to 1.96. The $\mathrm{C} / \mathrm{N}$ of bauxite residue was high, whilst $\mathrm{C} / \mathrm{P}$ and $\mathrm{N} / \mathrm{P}$ were comparatively low. Results showed that there was a significant difference in $\mathrm{C} / \mathrm{N}, \mathrm{C} / \mathrm{P}$ and N/P between BR1 and BR20, indicating the influence of natural weathering on the ecological stoichiometry of nutrients in residues. The mean range of $\mathrm{C} / \mathrm{N}$ is $10-12$ in China. The value of $\mathrm{C} / \mathrm{N}$ was as high as 101.45 in BR1, but fell significantly after 5 years of storage, and then gradually decreased to 12.41 after being stacked for 20 years; close to the average range of soil $\mathrm{C} / \mathrm{N}(P<0.05)$ (Wang and $\mathrm{Yu}$ 2008). This may be attributed to the low inputs of nitrogenous substances in the production of alumina, so nitrogen content is very low. However, with increasing duration following disposal, nitrogen gradually accumulates. Bauxite residue that had been stored for 20 years showed evidence of plant establishment. Plant litter, root exudates and decaying roots can effectively promote the accumulation of $\mathrm{OC}$ and $\mathrm{N}$, whereas $\mathrm{P}$ requires weathering processes to release it. As microorganism numbers increase, organic acid will be secreted to dissolve phosphorus, which they require to produce adenosine triphosphate (ATP) for cellular respiration (Moore et al. 2011). Almost all microbes are capable of utilizing inorganic phosphates, so inorganic phosphorus may be dissolved by mineralization, then organic phosphorus is released. This phenomenon may lead to a decrease in total phosphorus content and an increase in available phosphorus content. Further research is required to determine the drivers which directly or indirectly influence the variation of phosphorus availability and stacking age.

Redfield (1958) discovered that the C:N:P ratio is almost constant in marine plankton $(106: 16: 1)$, and that the ratio of $\mathrm{N}: \mathrm{P}$ in plankton is similar to deep seawater. 
The Redfield ratio compares the chemical processes in the oceans with biological processes that are organically linked and have important implications for terrestrial ecosystems (Moore et al. 2011). Subsequently, Cleveland and Liptzin (2007) found that soil carbon, nitrogen and phosphorus ratios also have significant stability, with a ratio 186:13:1, indicating that $\mathrm{C}, \mathrm{N}$ and $\mathrm{P}$ in different ecosystems have homeostatic characteristics (Jiao et al. 2013). Overall, the $\mathrm{C} / \mathrm{N}$ of bauxite residue revealed a descending trend, whilst $\mathrm{C} / \mathrm{P}$ and N/P showed a rising trend, with an increase in storage period. The average range of soil $\mathrm{C} / \mathrm{N}$ is $10-12$ in China, and the $\mathrm{C} / \mathrm{N}$ of bauxite residue for 20 year old stacks is close to this value (Wang and Yu 2008), but the C/P and N/P is much smaller than soil C/P and N/P (Cleveland and Liptzin 2007; Tian et al. 2010). Besides, there is a very significant positive correlation between $\mathrm{C}$ and $\mathrm{N}$ in bauxite residue $(P<0.01)$, indicating that changes in $\mathrm{C}$ and $\mathrm{N}$ are relatively consistent, and they are almost synchronous in stacking age, reaching homeostasis. So far, the lack of $\mathrm{C}$ and $\mathrm{N}$ in bauxite residue may lead to the low $\mathrm{C} / \mathrm{P}$ and $\mathrm{N} / \mathrm{P}$, so that nutrient cycling may be limited by carbon and nitrogen content.

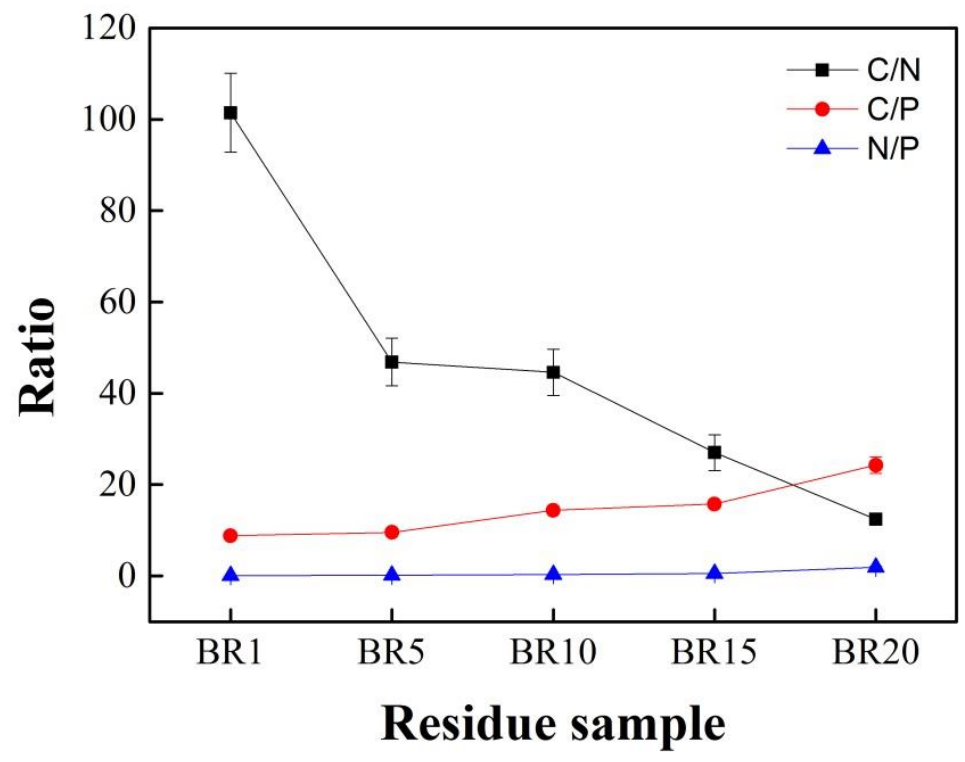

Fig.3 Ecological stoichiometry of bauxite residues in different stacking ages

In bauxite residue, $\mathrm{MBC} / \mathrm{MBN}$ has a range of 4.52 6.75, $\mathrm{MBC} / \mathrm{MBP}$ varies from 23.74 to 59.16, and MBN/MBP ranges from 4.52 to 6.32. Soil $\mathrm{MBC} / \mathrm{MBN}$ was 
6.67 8.00. In this study, this value reached a maximum of 6.75 in BR5, which was in the range of soil microbial biomass carbon-nitrogen ratio (Wright and Coleman 2000). The MBC/MBN was 5.25 in BR1 and 4.52 in BR20. For 5-year-old stacks it was significantly higher than that of residue from 1-year stacks. This ratio gradually decreased in the following 15 years, but it reached 9.4 on BRDAs with long-term storage and plant colonization, which was in the range for soil MBC/MBN. With increasing stacking years, $\mathrm{MBN} / \mathrm{MBP}$ and $\mathrm{MBC} / \mathrm{MBP}$ increased in bauxite residue, and both have significant differences between BR1 and BR20 $(P<0.05)$. However, MBC/MBP did not change significantly in bauxite residue that was stored for 5 or 20 years. There was no significant difference in MBN/MBP between BR15 and BR20. Overall, there were no obvious changes between microbial biomass stoichiometric characteristics, illustrating that the system was homeostatic. Huang and other researchers (Wardle 1998) believe that $\mathrm{MBC} / \mathrm{MBN}$ can be analyzed to reflect the microbial species and fauna. The $\mathrm{C} / \mathrm{N}$ ratio of bacteria is $\sim 5: 1$, actinomycetes $\sim 6: 1$, and fungus $10: 1$. Bacteria in bauxite residue stored for 1 year and 20 years were the greatest among the total number of microorganisms. The number of actinomycetes in bauxite residue stored for 5 years and 10 years was the greatest among the total number of microorganisms. Fungi in bauxite residue where plants were established was the highest among the total number of microorganisms, and this may be related to the mycorrhiza of the plant rhizosphere. 


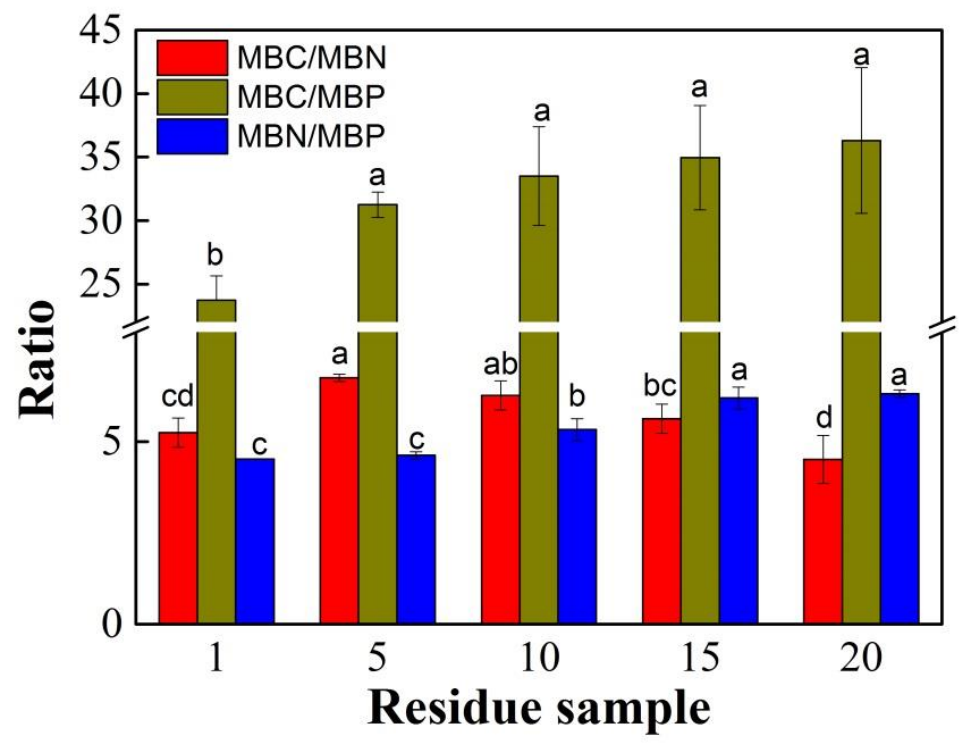

Fig.4 MBC, MBN and MBP ecological stoichiometry of bauxite residues in different stacking ages

The ratios between $\mathrm{C}, \mathrm{N}$ and $\mathrm{P}$ from different depths in BR20 are presented in Table 1. The $\mathrm{C} / \mathrm{N}$ of bauxite residue for 20 years was minimized at a depth of $20-40 \mathrm{~cm}$, and there was no significant difference between the surface and at a depth of $20-40 \mathrm{~cm}$ $(P<0.05) . \mathrm{C} / \mathrm{P}$ and N/P decreased with depth, and reached the greatest value in the surface of the residues. The effect of depth on microbial biomass ecological stoichiometry in BR20 is revealed in Table $1 . \mathrm{MBC} / \mathrm{MBN}$ consistently declined with depth from a maximum of 9.4 between $0-20 \mathrm{~cm}$ to a minimum of 4.6 between $40-60$ $\mathrm{cm}$. The $\mathrm{MBC} / \mathrm{MBP}$ and $\mathrm{MBN} / \mathrm{MBP}$ ratios between $0-20 \mathrm{~cm}$ significantly exceeded those of the respective ratios between $40-60 \mathrm{~cm}$ by 6.3 and 59.2 .

\section{Relationship between chemical properties and microbial biomass indices}

In residue samples, $\mathrm{MBC}, \mathrm{MBN}$ and $\mathrm{MBP}$ were positively correlated with $\mathrm{OC}$ and $\mathrm{TN}$ $(P<0.01)$, but negatively correlated with TP $(r=-0.899,-0.946$ and -0.928 , respectively; $P<0.01)$, revealing that $\mathrm{MBC}, \mathrm{MBN}$ and $\mathrm{MBP}$ are closely related to $\mathrm{C}, \mathrm{N}$ and $\mathrm{P}$ contents in bauxite residue. Therefore, MBC, MBN and MBP can be used as indicators to evaluate nutrient contents in bauxite residue, and organic matter, as important factors 
in accumulating microbial carbon and nitrogen. There was a negative correlation between $\mathrm{MBC}$ and $\mathrm{MBC} / \mathrm{MBN}(r=-0.270, P<0.01)$, but a positive correlation with $\mathrm{MBC} / \mathrm{MBP}$ and $\mathrm{MBN} / \mathrm{MBP}(r=0.731, P<0.01)$. Otherwise, there was no correlation between $\mathrm{MBN}$ and $\mathrm{MBC} / \mathrm{MBN}$. This means that the change in $\mathrm{MBC} / \mathrm{MBN}$ of bauxite residue is mainly related to $\mathrm{MBC}$. In addition, MBP was positively correlated with MBC/MBP and MBN/MBP $(r=0.792$ and $0.858, P<0.01)$.

Soil MBC/MBN, MBC/MBP is closely related to soil organic matter, and they are important indicators in reflecting organic matter content and nitrogen supply capacity. Previous studies showed that the lower the soil MBC/MBN and MBC/MBP, the more abundant of soil available nitrogen and phosphorus (Breuer et al. 2006). The $\mathrm{MBC} / \mathrm{MBN}$ in BR5 increased significantly compared with BR1, but then it gradually decreased, indicating an increase in nitrogen content after 5 years of storage. MBC/MBP increased gradually with stacking time, whilst AP in this study also increased (Fig. 1). This may be due to the absorption conversion efficiency of microbes being so high that the value of MBP is also high. This illustrates that microorganisms have a tendency to assimilate phosphorus in the residue, therefore playing a crucial role in phosphorus fixation. When plants establish, competition for effective phosphorus absorption by microorganisms and plants may occur (Zhao et al. 2013). During weathering, residue properties are improved, microbial flora changes, and finally these processes promote the ecological succession on BRDAs. 
Table 2 Correlation analysis of MBC, MBN, MBP and C, N, P in bauxite residue with different stacking years

\begin{tabular}{|c|c|c|c|c|c|c|c|c|c|}
\hline Parameters & $\mathrm{OC}$ & $\mathrm{TN}$ & TP & $\mathrm{C} / \mathrm{N}$ & $\mathrm{C} / \mathrm{P}$ & $\mathrm{N} / \mathrm{P}$ & MBC & MBN & MBP \\
\hline $\mathrm{TN}$ & $0.914 * *$ & & & & & & & & \\
\hline \multirow[t]{2}{*}{ TP } & - & - & & & & & & & \\
\hline & $0.948^{* *}$ & $0.910 * *$ & & & & & & & \\
\hline \multirow[t]{2}{*}{ MBC } & $0.874 * *$ & $0.737 * *$ & - & - & $0.840^{* *}$ & $0.669^{* *}$ & & & \\
\hline & & & $0.899 * *$ & $0.872 * *$ & & & & & \\
\hline \multirow[t]{2}{*}{ MBN } & $0.931 * *$ & $0.859 * *$ & - & - & $0.919^{* *}$ & $0.804 * *$ & $0.956^{* *}$ & & \\
\hline & & & $0.946^{* *}$ & $0.836^{* *}$ & & & & & \\
\hline \multirow[t]{2}{*}{ MBP } & $0.902 * *$ & $0.816^{* *}$ & - & - & $0.885^{* *}$ & $0.761 * *$ & $0.962 * *$ & $0.990 * *$ & \\
\hline & & & $0.928 * *$ & $0.856^{* *}$ & & & & & \\
\hline \multirow[t]{2}{*}{$\mathrm{MBC} / \mathrm{MBN}$} & $-0.550 *$ & - & 0.492 & 0.103 & $-0.583^{*}$ & $-0.628 *$ & - & -0.500 & -0.435 \\
\hline & & $0.624 * *$ & & & & & $0.270^{* *}$ & & \\
\hline \multirow[t]{2}{*}{$\mathrm{MBC} / \mathrm{MBP}$} & $0.894 * *$ & $0.959 * *$ & - & - & $0.929 * *$ & $0.962 * *$ & $0.731^{* *}$ & $0.831^{* *}$ & $0.792 * *$ \\
\hline & & & $0.890 * *$ & $0.708^{* *}$ & & & & & \\
\hline \multirow[t]{2}{*}{ MBN/MBP } & $0.892 * *$ & $0.775^{* *}$ & - & - & $0.870^{* *}$ & $0.709 * *$ & $0.907 * *$ & $0.909 * *$ & $0.858^{* *}$ \\
\hline & & & $0.885^{* *}$ & $0.750 * *$ & & & & & \\
\hline
\end{tabular}

\section{Conclusions}

In summary, freshly stacked bauxite residue at the BRDA in Central China was observed to be in poor condition, having low OC, TN and AP. Following disposal, and with time, vegetation begins to naturally colonize on the residue, and natural process improve the nutrient content. Furthermore, the ecological stoichiometry of C, $\mathrm{N}$ and $\mathrm{P}$ indicates that this ecosystem tends to become more stable with disposal time. We reveal that microbes are important in ecological restoration of bauxite residue. The ecological stoichiometry of $\mathrm{MBC}, \mathrm{MBN}$ and $\mathrm{MBP}$ are important indexes in evaluating the quality of bauxite residue. 


\section{References:}

Alshaal T, Domokos-Szabolcsy E, Márton L, Czakó M, Kátai J, Balogh P, Elhawat N, El-Ramady H, Fári M. 2013. Phytoremediation of bauxite-derived red mud by giant reed. Environ Chem Lett 11(3):295-302.

Anderson TR, Boersma M, Raubenheimer D. 2004. Stoichiometry: Linking elements to biochemicals. Ecology 85(5):1193-1202.

Breuer L, Huisman JA, Keller T, Frede HG. 2006. Impact of a conversion from cropland to grassland on $\mathrm{C}$ and $\mathrm{N}$ storage and related soil properties: Analysis of a 60 -year chronosequence. Geoderma 133(1):6-18.

Brookes PC, Landman A, Pruden G, Jenkinson DS. 1985. Chloroform fumigation and the release of soil nitrogen: A rapid direct extraction method to measure microbial biomass nitrogen in soil. Soil Biol Biochem 17(6):837-842.

Brookes PC, Powlson DS, Jenkinson DS. 1982. Measurement of microbial biomass phosphorus in soil. Soil Biol Biochem 14(4):319-329.

Babu AG, Reddy MS. 2011. Influence of arbuscular mycorrhizal fungi on the growth and nutrient status of bermudagrass grown in alkaline bauxite processing residue. Environ Pollut 159:25-29.

Heuck C, Weig A. Spohn M. 2015. Soil microbial biomass C:N:P stoichiometry and microbial use of organic phosphorus. Soil Biol Biochem 85:119-129.

Cleveland CC, and Liptzin D. 2007. C : N : P stoichiometry in soil: is there a "Redfield ratio" for the microbial biomass? Biogeochemistry 85(3):235-252.

Elser JJ, Urabe J. 1999. The stoichiometry of consumer-driven nutrient recycling: Theory, observations, and consequences. Ecology 80(3):735-751.

Elser JJ, Sterner RW, Gorokhova E, Fagan WF, Markow TA, Cotner JB, Harrison F, Hobbie SE, Odell GM, Weider LJ. 2000. Biological stoichiometry from genes to ecosystems. Ecol Lett 3(6):540-550.

Elser JJ, Fagan WF, Denno RF, Dobberfuhl DR, Folarin A, Huberty A, Interlandi S, Kilham SS, McCauley E, Schulz KL, Siemann EH, Sterner RW. 2000. Nutritional constraints in terrestrial and freshwater food webs. Nature 408(6812):578-580.

He ZL, Yang XE, Baligar VC, Calvert DV. 2003. Microbiological and biochemical indexing systems for assessing quality of acid soils. Adv Agron 78:89-138.

Jia GM, He L, Cheng H, Wang ST, Xiang HY, Zhang XF, Xi Y. 2016. Ecological Stoichiometry Characteristics of Soil Microbial Biomass Carbon, Nitrogen and Phosphorus Under Different Vegetation Covers in Three Gorges Reservoir Area. Res Soil Water Conserv 23(04):23-27.

Jiao F, Wen ZM, An SS, Yuan Z. 2013. Successional changes in soil stoichiometry after land abandonment in Loess Plateau, China. Ecol Eng 58:249-254.

Kong XF, Guo Y, Xue SG, Hartley W, Wu C, Ye YZ, Cheng QY. 2017. Natural evolution of alkaline characteristics in bauxite residue. J Clena Prod 143:224-230.

Li YF, Li QY, Liu HS, Li SJ, Wang YJ, Liu L. 2018. Ecological stoichiometry-based study of the influence of soil saline-alkali stress on nutrient homeostasis in L. chinensis. Ecotoxicol Environ Saf 165:243-249.

Mazzarino MJ, Szott L, Jimenez M. 1993. Dynamics of soil total C and N, microbial biomass, and water-soluble $\mathrm{C}$ in tropical agroecosystems. Soil Bio Biochem 25(2):205-214.

McGill W B, Cannon KR, Robertson JA, Cook FD. 1986. Dynamics of soil microbial biomass and 
water soluble organic $\mathrm{C}$ in Breton $\mathrm{L}$ after 50 years of cropping to two rotations. Can J Soil Sci 66(1):1-19.

Moore TR, Trofymow JA, Prescott CE, Titus BD. 2011. Nature and nurture in the dynamics of C, $\mathrm{N}$ and $\mathrm{P}$ during litter decomposition in Canadian forests. Plant Soil 339(1-2):163-175.

Peri PL, Gargaglione V, Pastur GM. 2008. Above- and belowground nutrients storage and biomass accumulation in marginal Nothofagus antarctica forests in Southern Patagonia. For Ecol Manag 255(7):0-2511.

Santini TC, Banning NC. 2016. Alkaline tailings as novel soil forming substrates: Reframing perspectives on mining and refining wastes. Hydrometallurgy 164:38-47.

Santini TC, Martin VF. 2013. Spontaneous vegetation encroachment upon bauxite residue (red mud) as an indicator and facilitator of in situ remediation processes. Environ Sci Technol (47):1208912096.

Santini TC, Peng NY. 2017. Microbial fermentation of organic carbon substrates drives rapid $\mathrm{pH}$ neutralisation and element removal in alkaline bauxite residue leachate. Environ Sci Technol 51:12592-12601.

Tian HQ, Chen GS, Zhang C, Melillo JM, Hall CAS. 2010. Pattern and variation of C:N:P ratios in China's soils: a synthesis of observational data. Biogeochemistry 98(1-3):139-151.

Wang SQ, Yu GR. 2008. Ecological stoichiometry characteristics of ecosystem carbon, nitrogen andphosphorus elements. Acta Ecol Sin 28(8):3937-3947.

Wang YP, Shen ZJ, Zhang Z. 2018. Phosphorus Speciation and Nutrient Stoichiometry in the SoilPlant System During Primary Ecological Restoration of Copper Mine Tailings. Pedosphere 28(3):530-541.

Wardle DA. 1998. Controls of temporal variability of the soil microbial biomass: A global-scale synthesis." Soil Bio Biochem 30(13):0-1637.

Wright CJ, Coleman DC. 2000. Cross-site comparison of soil microbial biomass, soil nutrient status, and nematode trophic groups. Pedobiologia 44(1):2-23.

Kong XF, Li M, Xue SG, Hartley W, Chen CR, Wu C, Li XF, Li YW. 2017. Acid transformation of bauxite residue Conversion of its alkaline characteristics. J Hazard Mater 324:382-390.

Yuan ZY, Chen HYH, Reich PB. 2011. Global-scale latitudinal patterns of plant fine-root nitrogen and phosphorus. Nat Commun 2(344).

Zhang ZS, Lu XG, Song XL, Guo Y, Xue ZS. 2012. Soil C, N and P stoichiometry of Deyeuxia angustifolia and Carex lasiocarpa wetlands in Sanjiang Plain, Northeast China. J Soils Sediments 12(9):1309-1315.

Zhao T, Yan H, Jiang YL, Huang YM, An SS. 2013. Effects of vegetation types on soil microbial biomass C, N, P on the Loess Hilly Area. Acta Ecol Sin 33(18):5615-5622.

Zhao SC, Li KJ, Zhou W, Qiu SJ, Huang SW, He P. 2016. Changes in soil microbial community, enzyme activities and organic matter fractions under long-term straw return in north-central China. Agric Ecosyst Environ 216:82-88.

Zhu F, Liao JX, Xue SG, Hartley W, Zou Q, Wu H. 2016. Evaluation of aggregate microstructures following natural regeneration in bauxite residue as characterized by synchrotron-based X-ray micro-computed tomography. Sci Total Environ 573:155-163.

Zhu F, Cheng QY, Xue SG, Li CX, Hartley W, Wu C, Tian T. 2018. Influence of natural regeneration on fractal features of residue microaggregates in bauxite residue disposal areas. Land Degrad Dev 29(1):138-149. 
Zhu F, Li XF, Xue SG, Hartley W, Wu C, Han FS. 2016. Natural plant colonization improves the physical condition of bauxite residue over time. Environ Sci Pollut Res 23(22):22897-22905. 
Table $1 \mathrm{C}, \mathrm{N}, \mathrm{P}$ content and their ecological stoichiometry at different depths of BR20

\begin{tabular}{|c|c|c|c|c|c|c|c|c|c|c|c|c|}
\hline $\begin{array}{l}\text { Depth } \\
(\mathrm{cm}\end{array}$ & $\begin{array}{c}\mathrm{OC} \\
(\mathrm{g} / \mathrm{kg})\end{array}$ & $\begin{array}{c}\mathrm{TN} \\
(\mathrm{g} / \mathrm{kg})\end{array}$ & $\begin{array}{c}\mathrm{TP} \\
(\mathrm{g} / \mathrm{kg})\end{array}$ & $\mathrm{C} / \mathrm{N}$ & $\mathrm{C} / \mathrm{P}$ & $\mathrm{N} / \mathrm{P}$ & $\begin{array}{c}\mathrm{MBC} \\
(\mathrm{mg} / \mathrm{kg})\end{array}$ & $\begin{array}{c}\mathrm{MBN} \\
(\mathrm{mg} / \mathrm{kg})\end{array}$ & $\begin{array}{c}\text { MBP } \\
(\mathrm{mg} / \mathrm{kg})\end{array}$ & $\mathrm{MBC} / \mathrm{MBN}$ & $\mathrm{MBC} / \mathrm{MBP}$ & MBN/MBP \\
\hline ) & & & & & & & & & & & & \\
\hline $0-20$ & $10.81 \mathrm{a} \pm 0.43$ & $0.87 \mathrm{a} \pm 0.08$ & $0.45 c \pm 0.02$ & $12.4 \mathrm{~b} \pm 1.11$ & $24.3 \mathrm{a} \pm 1.78$ & $2.0 \mathrm{a} \pm 0.19$ & $167.6 \mathrm{a} \pm 13.9$ & $37.4 \mathrm{a} \pm 3.43$ & $5.9 \mathrm{a} \pm 0.67$ & $9.4 \mathrm{a} \pm 0.2$ & $6.3 \mathrm{a} \pm 0.1$ & $59.2 \mathrm{a} \pm 1.3$ \\
\hline $20-40$ & $6.29 b \pm 0.16$ & $0.53 \mathrm{~b} \pm 0.06$ & $0.52 \mathrm{~b} \pm 0.01$ & $11.8 \mathrm{~b} \pm 1.07$ & $12.1 \mathrm{~b} \pm 0.31$ & $1.0 \mathrm{~b} \pm 0.12$ & $94.5 b \pm 12.3$ & $24.7 \mathrm{~b} \pm 1.39$ & $4.7 \mathrm{~b} \pm 0.43$ & $7.6 \mathrm{~b} \pm 0.1$ & $5.3 \mathrm{~b} \pm 0.4$ & $40.3 \mathrm{~b} \pm 2.5$ \\
\hline $40-60$ & $3.88 \mathrm{c} \pm 0.16$ & $0.16 \mathrm{c} \pm 0.02$ & $0.61 \mathrm{a} \pm 0.02$ & $25.3 \mathrm{a} \pm 4.25$ & $6.3 \mathrm{c} \pm 0.48$ & $0.3 \mathrm{c} \pm 0.02$ & $23.6 \mathrm{c} \pm 4.4$ & $8.38 \mathrm{c} \pm 0.97$ & $1.94 \mathrm{c} \pm 0.29$ & $4.6 \mathrm{c} \pm 0.1$ & $4.3 \mathrm{c} \pm 0.2$ & $19.8 \mathrm{c} \pm 1.1$ \\
\hline
\end{tabular}

Different lowercase letters $(\mathrm{a}, \mathrm{b}, \mathrm{c})$ mean significant difference $(P<0.05)$ among the same indexes in the same lines. 